\title{
Polypodiodes simonsiana (Polypodiaceae), a new fern from North East India and Myanmar
}

\section{Polypodiodes simonsiana (Polypodiaceae) - новый папоротник из Северо-Восточной Индии и Мьянмы}

\author{
C. R. Fraser-Jenkins ${ }^{1 *}$, A. P. Shalimov ${ }^{2}$ \\ К. Р. Фрейзер-Дженкинс ${ }^{1}$, А. П. Шалимов² \\ 'Student Guest House, Thamel, P.O. Box no. 5555, Kathmandu, Nepal.E-mail: chrisophilus@yahoo.co.uk \\ ${ }^{1}$ Студенческий гостевой дом, Тамель, Почтовый ящик № 5555, Катманду, Непал
}

${ }^{2}$ South-Siberian Botanical Garden, Altai State University, Lenina st., 61, Barnaul, 656049, Russia._E-mail: man_biol@mail.ru ${ }^{2}$ Южно-Сибирский ботанический сад, Алтайский государственный университет, Ленина, 61, Барнаул, 656049, Россия

$$
\text { *Corresponding author }
$$

Key words: Polypodiaceae, Polypodiodes, new fern, India, Myanmar, IUCN Red List. Ключевые слова: Polypodiaceae, Polypodiodes, новый папоротник, Индия, Мьянма, Красная книга МСОП.

Summary. Polypodiodes simonsiana Fraser-Jenk. et Shalimov, a new species of polypodiaceous fern from north eastern India and Myanmar, is described and illustrated. It is related to P. amoena (Wall. ex Mett.) Ching and P. niponica (Mett.) Ching, but is characterised by its prominently backward-deflexed, acutely pointed, elongated-triangular lower and mid pinnae, tapering evenly from their wide bases to their narrow acute apices. Its IUCN conservation status is assessed as VU (Vulnerable).

Аннотация. Приведено описание и изображение Polypodiodes simonsiana Fraser-Jenk. et Shalimov - нового вида полиподиевых папоротников из СевероВосточной Индии и Мьянмы. Описываемый вид родственен $P$. amoena (Wall. ex Mett.) Ching и P. niponica (Mett.) Ching, но существенно отличается от обоих загнутыми книзу, удлиненно-треугольными нижними и средними долями пластинки, равномерно суженными к острой верхушке. Охранный статус $P$. simonsiana по системе категорий МСОП оценивается как VU (уязвимый).

\section{Introduction}

The genus Polypodiodes Ching is related to Goniophlebium (Blume) C. Presl and contains about 10 species (Ching, 1978; Fraser-Jenkins 1997, 2008; Lu, Hovenkamp, 2013). They are readily distinguished from Goniophlebium in having sessile pinnae joined together at their bases, as opposed to fully separated pinnae, and form a natural group. A few authors have included the genus within Goniophlebium, notably Rödl-Linder (1990), and Smith et al. (2006), followed automatically by Lindsay et al. (2009). A recent attempted molecular reclassification by Christenhusz and Chase (2014) also did not accept the genus, but entirely failed to take important morphological considerations into account in their survey of taxa and was diametrically opposed to Christenhusz et al. (2011), neither of which schemes are taxonomically acceptable. Polypodioides species are fairly narrowly distributed in subtropical Asia, from Japan, Taiwan and China to northern India and in Myanmar, Thailand and the Indochinese Peninsula, and most of them are either epiphytes or lithophytes occurring at upper-mid to higher altitude. Superficially they are of similar aspect to the more northerly genus Polypodium L. and in older British-Indian literature were so placed.

Fraser-Jenkins (1997, 2008a, b) identified and gave details of a distinctive plant from Myanmar and N. E. India as "P. wattii (Bedd.) Tagawa", a specimen of which (F. Kingdon Ward 21396, 
BM) had first been noticed and annotated by the late Dr. A. H. G. Alston as being a distinct new species, which he thought incorrectly to be related to P. subamoena (C. B. Clarke) Ching. Although he agreed with Alston's recognition of the species as distinct, Fraser-Jenkins misapplied the name $P$. wattii to it because some other material of it at the BM had been misdetermined as that species. Only later, after 2008, he realised the true identity of $P$. wattii, which is a synonym of $P$. niponica (Mett.) Ching, despite being separated as a variety by RödlLinder (1990) and even as a species by $\mathrm{Lu}$ and Hovenkamp (2013). This left the present species without a name, which he provided for it (Ebihara et al., 2012; Fraser-Jenkins, 2012) as Polypodiodes simonsiana, named after the first botanist to collect it. He also provided a photograph of the holotype as the home page of the Indian Ferns website (www. groups.yahoo.com/group/Indian-Ferns) in 2009. However, the name was not validated until now, so we validate it here and describe the species below.

\section{Taxonomic details}

Polypodioides simonsiana Fraser-Jenk. et Shalimov, sp. nov. (Fig. 1, 2)

Epiphytic fern. Rhizome long creeping, up to $5 \mathrm{~mm}$ thick, drying black, without whitish blume; scales on the rhizome very scattered or largely absent except towards the apices, absent from the stipe-base. Stipe green, drying stramineous, 10-15 $\mathrm{cm}$. Lamina oblong-lanceolate, up to $50 \mathrm{~cm}$ long and to $9 \mathrm{~cm}$ wide, pinnate, but becoming pinnatifid towards the apex. Segments $20-30$ pairs, $2-5 \times 0.5-$ $1 \mathrm{~cm}$., elongate-triangular and tapering evenly to the acutely pointed apex, rather insignificantly dentate at the margin, their bases widened and narrowly decurrently winged (1-2 mm wide) onto the rachis, where they are just confluent with the adjacent one. Lowest pair of pinnae markedly deflexed and those in the lowest half of the lamina also \pm deflexed. Veins anastomosing to form 1 row of areoles on each side of the rachis and each side of the pinna-costa, veinlets evident. Lamina herbaceous, grey-green, glabrous and without pubescence on both surfaces, nor on the rachis. Sori orbicular, in 1 row on each side of the pinna-costa, nearer to the costa than the margin, spores ellipsoid.

Holotype: Myanmar, Kachin state: "North Burma, North Triangle (Arahku), a hanging epiphyte in the subtropical forest, leaves somewhat glaucous, $4000 \mathrm{ft}$., F. Kingdon Ward 21396, 30 September 1953" (BM); det. A. H. G. Alston as "Polypodium sp. nov. aff. subamoena Wall.".

Other specimens seen: Chin Hills, Mt. Victoria.

Distribution: N. E. India (Arunachal Pradesh, Manipur, Meghalaya), Myanmar.

Habitat and ecology: Pendent epiphyte in subtropical forest, c. $1220 \mathrm{~m}$ altitude.

IUCN Red List category: Because of the rather few herbarium collections known only from a few localities in N. E. India and Myanmar, Chandra et al. (2008), Fraser-Jenkins (2012) and in Ebihara et al. (2012) assessed its status as Vulnerable (VU) according to IUCN criteria.

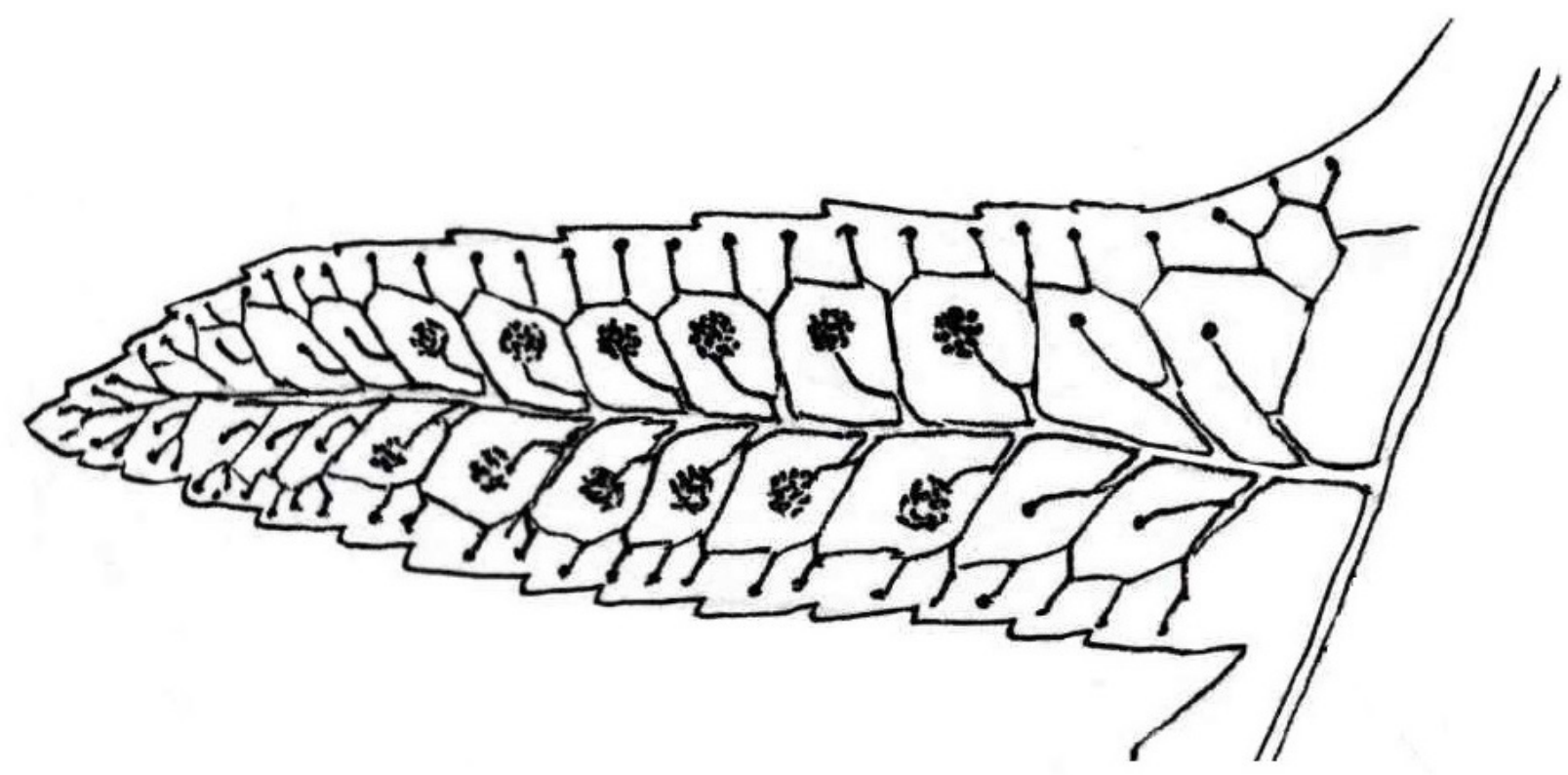

Fig. 1. Detail of venation and position sorus (All: F. Kingdon Ward 21396, BM). 


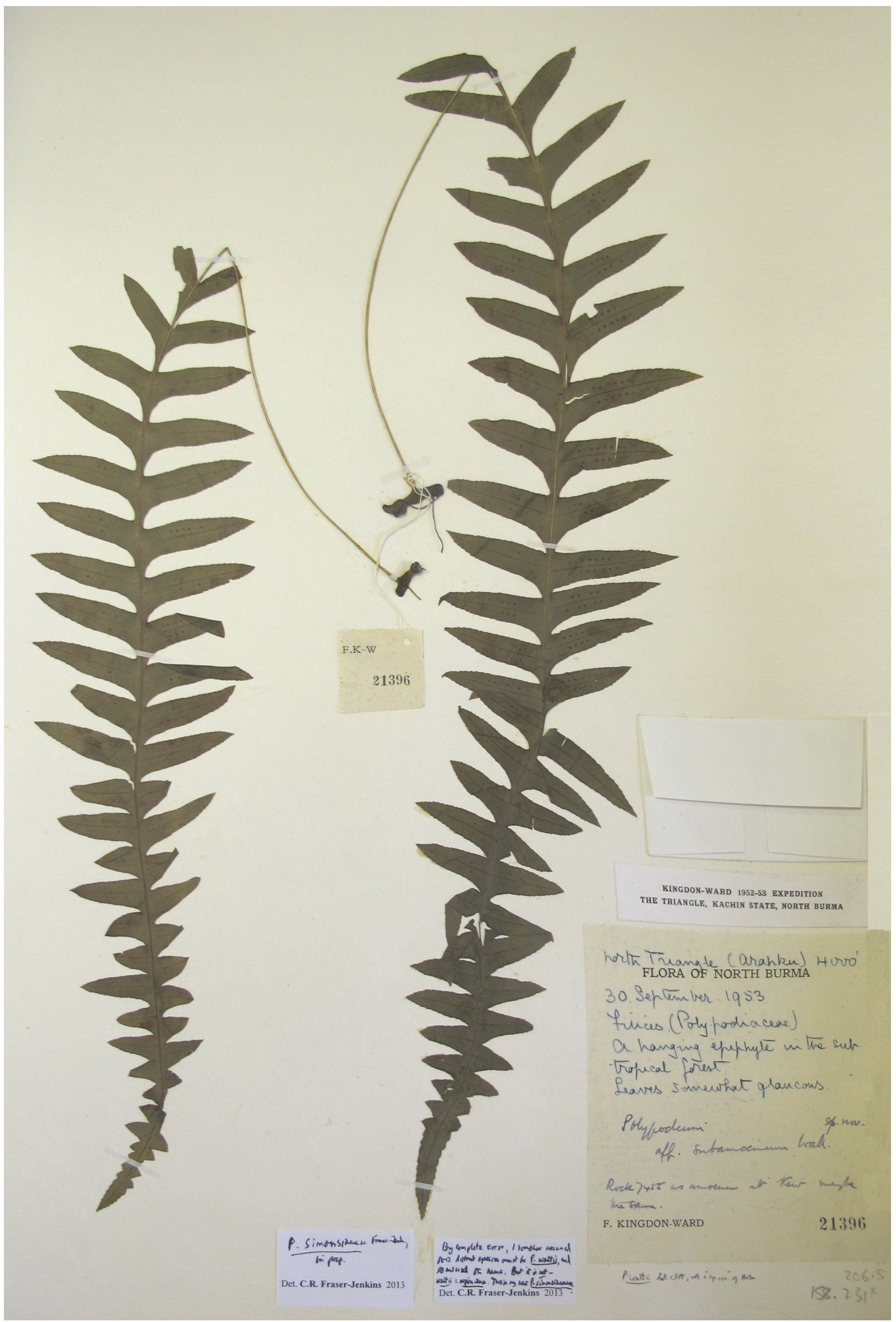

Fig. 2. Photo of the holotype of Polypodioides simonsiana Fraser-Jenk. et Shalimov. 


\section{Discussion}

The new species is morphologically close to $P$. niponica and P. amoena, however P. simonsiana can be discriminated from them by its naked black rhizome, without a white blume and almost without scales except towards the apices. The lamina of $P$. simonsiana is oblong-lanceolate, with a wider base and many lobes directed downwards, in contrast to $P$. niponica with a narrowly ovate-lanceolate lamina, and only the lowest pair of pinnae directed downwards. The pinnae of $P$. simonsiana are markedly elongated triangular with a narrowly pointed apex, unlike the more oblong pinnae, with more rounded apices of $P$. niponica, or the much longer pinnae of $P$. amoena. The surface of the lamina and rachis in $P$. simonsiana are naked, which also distinguishes it from $P$. niponica, which has the lamina covered with rather dense, whitish soft hairs.

\section{LITERATURE}

Chandra S., Fraser-Jenkins C. R., Kumari A., Srivastava A. A summary of the status of threatened Pteridophytes of India// Taiwania, 2008. - Vol. 53, No. 2. - P. 170-209. [reprinted with additions sub Chandra S., Fraser-Jenkins C. R. in Verma S. C., Khullar S. P., Cheema H. K. (eds.) 11. Perspectives in Pteridophytes, Silver Jubilee Publication of Indian Fern Society (1983-2008). - Bishen Singh Mahendra Pal Singh, Dehra Dun, 2008. - P. 199-224].

Ching R.-C. The Chinese fern families and genera: systematic arrangement and historical origin (cont.) // Acta Phytotaxonomica Sinica, 1978. - Vol. 16, No. 4. - P. 16-37.

Christenhusz M. J. M., Chase M. W. Trends and concepts in fern classification // Annals of Botany, 2014. - Vol. 113. - P. 571-594. [doi:10.1093/aob/mct299]

Christenhusz. M. J. M., Zhang X.-Ch., Schneider H. A linear sequence of extant families and genera of lycophytes and ferns // Phytotaxa, 2011. - Vol. 19. - P. 7-54.

Ebihara A., Fraser-Jenkins C. R., Parris B. S., Zhang X.-C., Yang Y.-H., Chiou W.-L., Chang H.-M., Lindsay S., Middleton D., Kato M., Praptosuwiryo T.N., Amoroso V.B., Barcelona J.F., Ranil R. H. G., Park C.-H., Murakami N., Hoya A. Rare and threatened Pteridophytes of Asia 1. Anenumeration of narrowly distributed taxa // Bulletin of the Natural Museum of Nature and Science. Series B, Botany, 2012. - Vol. 38, No. 3. - P. 93-119.

Fraser-Jenkins $\boldsymbol{C}$. $\boldsymbol{R}$. New species syndrome in Indian pteridology and the ferns of Nepal: i-v, with separate errata. - International Book Distributors, Dehra Dun, India, 1997. - 403 p.

Fraser-Jenkins $\boldsymbol{C}$. $\boldsymbol{R}$. Endemics and pseudo-endemics in relation to the distribution patterns of Indian Pteridophytes // Taiwania, 2008a. - Vol. 53, No. 3. - P. 264-292.

Fraser-Jenkins $\boldsymbol{C}$. $\boldsymbol{R}$. Taxonomic revision of three hundred Indian subcontinental Pteridophytes with a revised census-list - a new picture of fern-taxonomy and nomenclature in the Indian subcontinent: Bishen Singh Mahendra Pal Singh, Dehra Dun, India, 2008b. - 685 p., t. 1-255.

Fraser-Jenkins $\boldsymbol{C}$. $\boldsymbol{R}$. Rare and threatened Pteridophytes of Asia 2. Endangered species of India - the Higher IUCN Categories // Bulletin of the Natural Museum of Nature and Science. Series B, Botany, 2012. - Vol. 38, No. 4. - P. 153-181.

Lindsay S., Middleton D. J., Boonkerd T., Suddee S. Towards an unstable nomenclature for Thai ferns // Thai Forest Bulletin. Botany. - Bangkok, 2009. - Vol. 37. - P. 64-106.

Lu S.-G., Hovenkamp P. H. Polypodiodes Ching // Flora of China. - Vol. 2-3 (Pteridophytes) / Ed. by Z. Y. Wu, P. H. Raven, D. Y. Hong. - Beijing: Science Press; St. Louis: Missouri Botanical Garden Press, 2013. - P. 800-804.

Röde-Linder G. A monograph of the fern genus Goniophlebium (Polypodiaceae) // Blumea, 1990. - Vol. 34. - P. 277-423.

Smith A. R., Pryer K. M., Schuettpelz E., Korall P, Schneider H., Wolff P. G. A classification for extant ferns // Taxon, 2006. - Vol. 55, No. 3. - P. 705-731. 